\title{
Assessing the Impact of Total Quality Management Practices and Quality Culture with Competitiveness of Saudi Contractors
}

\author{
${ }^{1}$ Faihan Alotaibi, ${ }^{1}$ Rushami Zien Yusoff and ${ }^{2}$ Rabiul Islam \\ ${ }^{1}$ School of Business Management (SBM), College of Business, \\ University Utara University Malaysia, 06010 UUM, Kedah, Malaysia \\ ${ }^{2}$ School of Economics, Finance and Banking, College of Business, \\ University Utara University Malaysia, 06010 UUM, Kedah, Malaysia
}

Received 2013-05-06, Revised 2013-06-10; Accepted 2013-06-30

\begin{abstract}
Total quality management practices in construction industries can be described as the processes or that aligns the business performance strategy to the business processes in the hopes of achieving customer satisfaction and product and services quality. Quality culture conditions are strongly linked with project outcomes and hence, initiatives undertaken should be incorporated to the organizational cultural changes. The aim of the study is to determine the impact of total quality management practices, quality culture and their relationship with the competitiveness of Saudi Arabia contractors. A quantitative research design was adopted to collect data and test hypotheses. A cross-sectional survey method was used to conduct this study. The findings of the study will contribute to both theory and practice. Through the present study, the researcher expects the findings to indicate that total quality management practices meaningfully contributed and related to competitiveness and developing cooperative relationship with customers; practices that are related to the achievement of continuous improvement and in turn, continuous improvement affects quality outcomes.
\end{abstract}

Keywords: Total Quality Management Practices, Quality Culture, Relationship, Competitiveness, Contractors

\section{INTRODUCTION}

Total Quality Management (TQM) practices are being widely adopted by contractor companies to solve problems regarding quality in the construction industry particularly to satisfy the needs of the customers (Fung and Wong, 1995; Kanji and Wong, 1998). It is no surprise that TQM has now become the major business strategy in current management and has currently been taken up by companies around the globe (Rad, 2006). The construction industry is being considered as comparatively having one of the poorest quality emphases among different manufacturing and service sectors (Wong and Fung, 1999). In fact, numerous criticisms have been heaped on the construction industry for the general under quality of workmanship. This relates to the final product and processes that the products undergo, the peoples and the materials (Mahmood et al., 2006). Thus, the present study is confined to TQM implementation in the contractor companies in general and the Saudi classified contractor companies in particular.

The relation between the total quality management practices and competitiveness is such that several organizations are failing to achieve competitive advantage through TQM practices' implementation while some others have succeeded. The failure is attributed to the incomplete implementation of the crucial TQM practices and the absence of the assisting assets that must be simultaneously used with TQM for the achievement of competitive advantage (Douglas and Judge, 2001).

Corresponding Author: Faihan Alotaibi, School of Business Management, College of Business, University Utara University, Malaysia, 06010 UUM, Kedah, Malaysia 
The competitiveness concept has been defined in multitude of ways; in the individual firm's context, industries context and nation's context (Alotaibi et al., 2013). TQM practices implementation comes the monumental changes that affect elements such as: Organizational structure, quality culture, leadership, or design process. Hence, it goes without saying that the implementation of TQM should have its basis on the culture, beliefs, traditions and tailor-designed TQM strategies. TQM's core principle is based on the fact that all other business objectives like profit, productivity, market share growth, happy employees, must stem from the single objective of customer satisfaction (Bagchi, 1997).

Quality culture may be considered to encompass all the institutionalized ways and the implicit beliefs, norms and values and premises which underline and govern behaviour (Ahmed et al., 1999). Various countries, nations, regions and enterprises generally project different feelings, requirements, creations and understanding from each other. The researchers have still not reached a unanimous definition of quality culture. Douglas and Judge (2001), on the other hand, advocate the fact that quality culture can be investigated in both broad and narrow points of view. In the former, it is considered to be phases of consciousness, standards, value orientation, codes of conduct modes of thoughts and manners and customers regarding quality issues developed through a long term production and operating activities of firms and society and the totality of products, identifications and actions, (Douglas and Judge, 2001).
Competition is often considered as the contest between two or more than two entities for a certain attractive target or goal. Generally speaking, the dictionary meaning of competitiveness is often an aggressive willingness to compete. Aggressiveness is considered as the quality of boldness and enterprising. A competition commonly has three elements to make it so: main interests of the independent competition, competitors and the result of competition (Shi-Rong and Guang-Kun, 2008). Porter (2003), defines competitiveness as the country's share of world markets for its products. From this definition, it can be assumed that competitiveness is a zero-sum game due to the competitiveness of one country at the expense of other countries. Holt et al. (1994), provided a classification of competitiveness indicators into five categories; contractor's organization, financial considerations, management resource, past experience and past performance. Every group comprises of particular indicators.

\section{MATERIALS AND METHODS}

The conceptual framework is adopted from three comprehensive variables which include TQM, quality culture and competitiveness. TQM is the single component considered as the independent variable while the dependent variables consist of competitiveness. In addition, quality culture will be considered as the mediating variable in the relationship between TQM practices and competitiveness in Fig. 1.

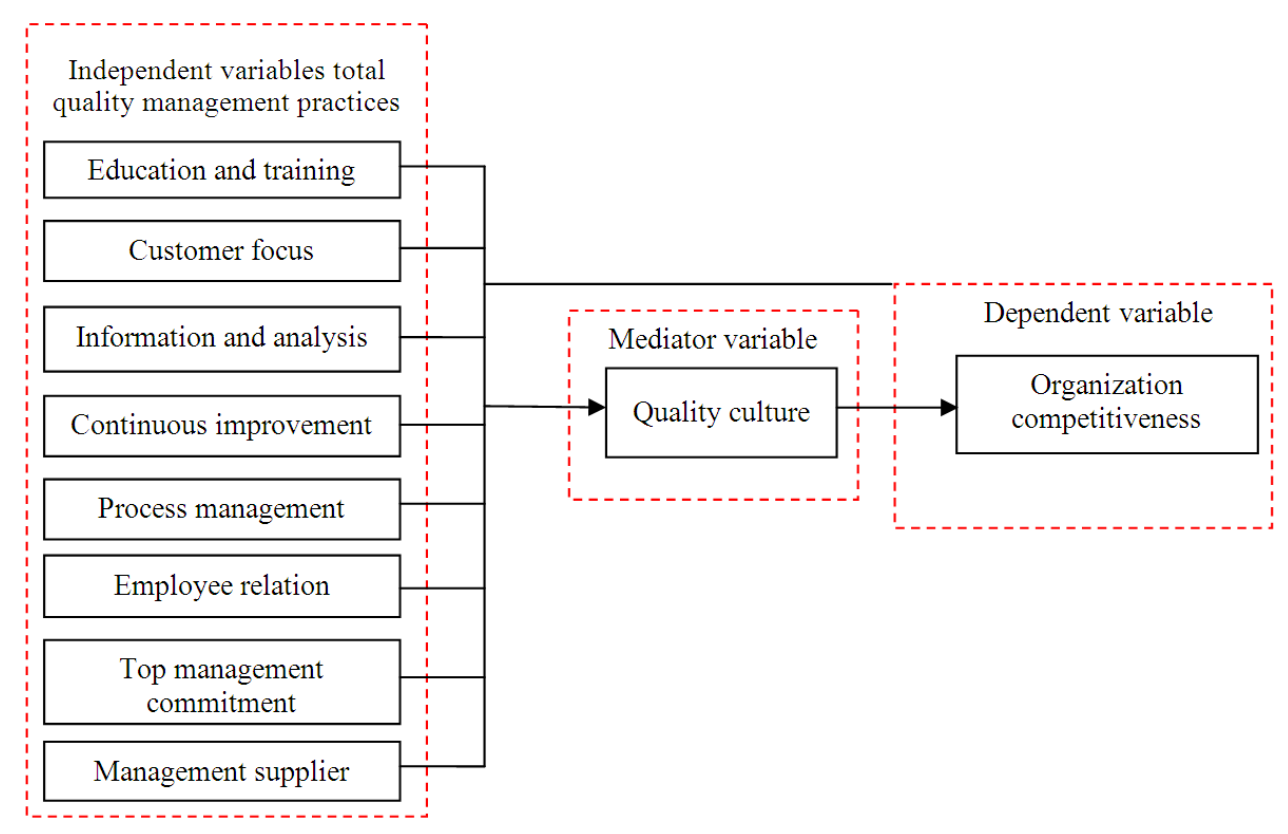

Fig. 1. Conceptual framework 
It is notable that when quality culture is intended to be studied as the mediating factor, the theoretical model becomes one of a kind. As evidenced by (Abdullah et al., 2009), quality culture is a fundamental element in such research model and based on a thorough review of literature, there is lack of studies investigating the role of quality culture as a mediating variable between TQM and Companies' competitiveness in Saudi construction companies. Therefore, the justification of the present study attempting to utilize the same as a mediating variable for the purpose of the investigation between TQM and competitiveness is valid. Figure 1 presents the cconceptual framework of the present study.

There are the following hypotheses:

- H1: Total quality management practices are associated with competitiveness

- H2: Total quality management practices are associated with quality culture

- H3: Quality culture is associated with competitiveness

- H4: Quality culture mediates the relationship between total quality management practices and competitiveness

\section{RESULTS}

\subsection{Reliability Test}

Pallant (2001), research concluded that new measures of scales should have reliability to the extent of minimum 0.60. Reliability implies the reference to making assessments of the extent to which there is uniformity amongst the varied measurements of the variables (Hair et al., 2006). Thus, it can be said that this process serves as a means to measure levels of consistency of the given performance levels and behaviours. According to (Sekaran, 2003). Cronbach's alpha has been very frequently used as an indicator for representing the appropriate indication levels relative to reliance and internal consistency. It is mostly agreed that the most widely accepted value for Cronbach's alpha turns out to be 0.70 and above (Hair et al., 2006).

Table 1 below summarizes the reliance tests of the different items. As evident, the Cronbach's alpha in terms of measurements related to the lower limits of acceptance is found to be such that $\alpha>0.70$. In view of such circumstances, all measures were found to be having considerable reliability.

\subsection{Descriptive Analysis}

For the purpose of descriptive analysis, the mean and standard deviation are computed.
Table 1. Reliability results

\begin{tabular}{llll}
\hline Variables & Variables & $\begin{array}{l}\text { No. of } \\
\text { items }\end{array}$ & $\alpha$ \\
\hline Total quality & & & \\
management & & & \\
practices & Education and training & 4 & 0.899 \\
& Customers focus & 4 & 0.930 \\
& Information and analysis & 4 & 0.817 \\
& Continuous and improvement & 3 & 0.766 \\
& Process management & 4 & 0.887 \\
& Employee relations & 7 & 0.929 \\
& Top management commitment & 4 & 0.884 \\
Quality culture & Management of supplier & 4 & 0.803 \\
& Improvement orientation & 6 & 0.929 \\
& Team work orientation & 4 & 0.893 \\
& Mission and goal orientation & 5 & 0.918 \\
& Management style & 4 & 0.853 \\
& Personal influence performance & 6 & 0.947 \\
Competitiveness & Task environment & 5 & 0.840 \\
& Corporate image & 6 & 0.933 \\
& Technology and innovation & 3 & 0.862 \\
& Marketing capability & 4 & 0.889 \\
& Financial capability & 4 & 0.876 \\
& Project management skill & 4 & 0.720 \\
\hline
\end{tabular}

Table 2. Means and standard deviations for all variables

\begin{tabular}{lll}
\hline Variables & $\mathrm{M}$ & $\mathrm{SD}$ \\
\hline $\begin{array}{l}\text { Total quality management } \\
\text { Practices (TQMP) }\end{array}$ & 3.69 & 0.39 \\
Quality Culture (QC) & 3.68 & \\
Competitiveness (C) & 3.77 & 0.45 \\
\hline
\end{tabular}

Table 3. Cohen's guideline of correlation strength

\begin{tabular}{ll}
\hline$r$ & Strength of relationship \\
\hline 0.10 to $0.29 /-0.10$ to -0.29 & Low \\
0.30 to $0.49 /-0.30$ to -0.49 & Moderate \\
0.50 to 1.0 or $/-0.50$ to -0.1 .0 & High \\
\hline
\end{tabular}

$\underline{\text { Table 4. Summary of correlations of variables }}$

\begin{tabular}{lll}
\hline Study variables & $\begin{array}{l}\text { Correlation } \\
\text { coefficient }\end{array}$ & $\begin{array}{l}\text { Strength of } \\
\text { relationship }\end{array}$ \\
\hline TQMP and competitiveness & $0.412^{* *}$ & Moderate \\
TQMP and quality culture & $0.762^{* *}$ & High \\
$\begin{array}{l}\text { Quality culture and } \\
\text { competitiveness }\end{array}$ & $0.353^{* *}$ & Moderate \\
\hline$*$ p $<0.01$ & &
\end{tabular}

As portrayed in Table 2, it can be observed that the mean scores of TQMP indicated a high level of TQMP with $3.69(\mathrm{SD}=0.39)$. For the Quality Culture the mean was $3.68(\mathrm{SD}=0.45)$, which indicated a high level of agreement. Furthermore, Competitiveness indicated a high level of Competitiveness with $3.77(\mathrm{SD}=0.36)$. 
Table 5. Statistic values of Skewness and Kurtosis (Descriptive statistics)

\begin{tabular}{|c|c|c|c|c|}
\hline \multirow[b]{2}{*}{ Variables } & \multicolumn{2}{|c|}{ Skewness } & \multicolumn{2}{|l|}{ Kurtosis } \\
\hline & Statistic & Std. error & Statistic & Std. error \\
\hline Total quality management practices & 0.286 & 0.124 & 0.167 & 0.247 \\
\hline Quality culture & -0.250 & 0.124 & 0.840 & 0.247 \\
\hline Competitiveness & -0.052 & 0.124 & -0.246 & 0.247 \\
\hline
\end{tabular}

Table 6. Durbin-Watson statistical value

\begin{tabular}{lllllll}
\hline Model & IV & DV & R square & Adjusted R square & Std. error of the estimate & Durbin-Watson \\
\hline 1 & TQMP & Competitiveness & 0.170 & 0.168 & 0.33484 & 1.507 \\
2 & TQMP & Quality culture & 0.580 & 0.579 & 0.29397 & 1.782 \\
3 & Quality culture & Competitiveness & 0.125 & 0.122 & 0.34384 & 1.576 \\
\hline
\end{tabular}

\subsection{Correlation Analysis}

Correlation analysis is a statistical method used to describe the strength and direction of the linear relationship between two variables (Pallant, 2001). The degree of correlation concerned is to measure the strength and importance of a relationship between the variables. Pearson's correlation coefficient (r) with significance levels was utilised in order to assess the correlations between the variables. Cohen (1988), has provided a guideline to explain the strength and the degree of the correlation between two variables as presented in Table 3. In Table $\mathbf{4}$, a summary of the variables' correlations is presented.

\subsection{Regression Analysis}

All the variables were tested using skewness and kurtosis levels to determine normality. According to (Hair et al., 1998), the acceptable level of skewness and kurtosis is between-2.00 and +2.00 at the significance level of 0.05 . It is clear from Table 5 that none of the variables showed skewness or kurtosis over 2.0, implying that data was suitably distributed. It indicates that analysis of skewness and kurtosis at univariate levels results to prior confirmation of multivariate normality only.

\subsection{Independence of Error Term}

For the purpose of making an assessment and validation of the independence of error assumptions, the Durbin-Watson statistics were utilized. Based on (Coakes, 2003), the independence of error term is considered invalid if the Durbin-Watson values are between 1.50 and 2.50. For the present study, the Durbin-Watson value is summarized in Table 6. The result shows that the value declined among the acceptable values, indicating that auto-correlation problems are not found.
Table 7. Correlation coefficients of research factors $(\mathrm{N}=388)$

\begin{tabular}{lc}
\hline Factors & Quality culture \\
\hline Competitiveness & 1.000 \\
Education and training & $0.274(* *)$ \\
Customers focus & $0.508(* *)$ \\
Information and analysis & $0.335(* *)$ \\
Continuous improvement & $0.286(* *)$ \\
Process management & $0.169(* *)$ \\
Employee relations & $0.555(* *)$ \\
Top management commitment & $0.478(* *)$ \\
Management of supplier & $0.245(* *)$ \\
\hline
\end{tabular}

$* * \mathrm{p}<0.01$

\section{DISCUSSION}

\subsection{Total Quality Management Practices and Quality Culture}

In order to investigate the relationship between TQMP factors and the Quality Culture, Pearson correlation coefficient was used. Table 7 shows the results of the correlation test between TQMP factors and the Quality Culture.

In order to answer this research question and test the research hypotheses linear regression analysis is conducted. The analysis helps determine the contribution of every factor and pinpoints the factor that is the best predictor of any outcome. The TQMP factors explained a significant percentage of variance in Quality Culture $\mathrm{R}^{2}$ $=0.681, \mathrm{~F}=101.278, \mathrm{p}<0.001$.

In general, the higher the mean value, the higher level of agreement with the statements and the smaller the standard deviation the more concentrated the data around the mean (Jennings and Loan, 2001). For ease interpretation, the range of five point likert-scale was categorized into equal sized; categorized as low, moderate and high. Hence, scores of less than 2.33 (4/3 +lowest value 1) are considered as low; scores of higher than 3.67 (highest value (5)-4/3) are considered as high and those in between are considered moderate. 
Faihan Alotaibi et al. / American Journal of Applied Sciences 10 (6): 638-645, 2013

Table 8. Multiple linear regression analysis between Total Quality Management Practices (TQMP) Factors as IVs and Quality Culture as DV

\begin{tabular}{|c|c|c|c|c|c|c|}
\hline Model & $\mathrm{R}$ & $\mathrm{R}^{2}$ & Adjusted $\mathrm{R}^{2}$ & \multicolumn{3}{|c|}{ Std. error of the estimate } \\
\hline \multicolumn{7}{|l|}{ Model summary } \\
\hline 1 & $0.605(a)$ & 0.366 & 0.353 & 0.2953 & & \\
\hline Model & Sum of Squares & df & Mean Square & $\mathrm{F}$ & P. & \\
\hline \multicolumn{7}{|l|}{$\operatorname{ANOVA}(b)$} \\
\hline \multirow[t]{4}{*}{1} & 54.145 & 8 & 6.768 & 101.278 & $0.000(a)$ & \\
\hline & 25.327 & 379 & 0.067 & & & \\
\hline & 79.472 & 387 & & & & \\
\hline & & \multicolumn{5}{|c|}{ Unstandardized } \\
\hline Model & & $\mathrm{B}$ & Std. Error & $\begin{array}{l}\text { S.zed } \\
\text { Beta }\end{array}$ & $\mathrm{t}$ & P. \\
\hline \multicolumn{7}{|l|}{ Coefficients (a) } \\
\hline \multirow[t]{9}{*}{1} & (Constant) & 0.385 & 0.143 & & 2.689 & $0.000 * * *$ \\
\hline & Education and training & 0.131 & 0.012 & 0.323 & 10.796 & $0.000 * * *$ \\
\hline & Customers focus & 0.164 & 0.021 & 0.276 & 7.977 & $0.000 * * *$ \\
\hline & Information and analysis & -0.031 & 0.024 & 0.045 & -1.281 & 0.201 \\
\hline & Continuous improvement & 0.017 & 0.021 & 0.027 & 0.816 & 0.415 \\
\hline & Process management & 0.004 & 0.014 & 0.010 & 0.328 & 0.743 \\
\hline & Employee relations & 0.245 & 0.017 & 0.475 & 14.740 & $0.000 * * *$ \\
\hline & Top management commitment & 0.207 & 0.023 & 0.304 & 8.885 & $0.000 * * *$ \\
\hline & Management of supplier & 0.092 & 0.026 & 0.144 & 3.517 & $0.000 * * *$ \\
\hline
\end{tabular}

Table 9. Correlation coefficients of research factors $(\mathrm{N}=388)$

\begin{tabular}{ll}
\hline Factors & Competitiveness \\
\hline Competitiveness & 1.000 \\
Quality culture & $0.762(* *)$ \\
\hline$* * \mathrm{p}<0.01$ &
\end{tabular}

Table 8 shows the results of multiple linear regression analysis between TQMP factors (education and training, customers focus, information and analysis, continuous improvement, process management, employee relations, top management commitment and management of supplier) and Quality Culture.

As portrayed in Table 8, the results indicated that five TQMP (Education and Training, Customers Focus, Employee relations, Top Management Commitment, Management of supplier) factors significantly affect Quality Culture while three TQMP factors (Information and Analysis, Continuous Improvement, Process Management) have no significant effect on Quality Culture.

\subsection{Quality Culture and Competitiveness}

In order to investigate the relationship between Quality Culture and Competitiveness, Pearson correlation coefficient was used. Table 9 shows the results of the correlation test between Quality Culture and Competitiveness. It is found in the table that the quality culture variable explain a significant percentage of variance in competitiveness $\left(\mathrm{R}^{2}=0.125, \mathrm{~F}=54.985, \mathrm{p}<0.001\right)$. Therefore, quality culture variable explain $12.5 \%$ of the total variance in competitiveness. In short, above hypothesis is supported. In detail, Table $\mathbf{1 0}$ explains that the regression model supports hypothesis the above.

Therefore, TQMP factors (education and training, customers focus, information and analysis, continuous improvement, process management, employee relations, top management commitment and management of supplier) explained $68.1 \%$ of the total variance in Quality Culture.

\subsection{Quality Culture Mediates the Relationship between Total Quality Management Practices and Competitiveness}

In order to investigate the relationship between total quality management practices and the contractors' competitiveness, Pearson correlation coefficient was used. Table 11 shows the results of the correlation test between TQMP factors and the contractors' competitiveness.

Table 12 shows the results of multiple regression analysis between TQMP factors (education and training, customers focus, information and analysis, continuous improvement, process management, employee relations, top management commitment and management of supplier) and contractors' competitiveness. 
Faihan Alotaibi et al. / American Journal of Applied Sciences 10 (6): 638-645, 2013

Table 10. Simple linear regression analysis between quality culture as IV and competitiveness as DV

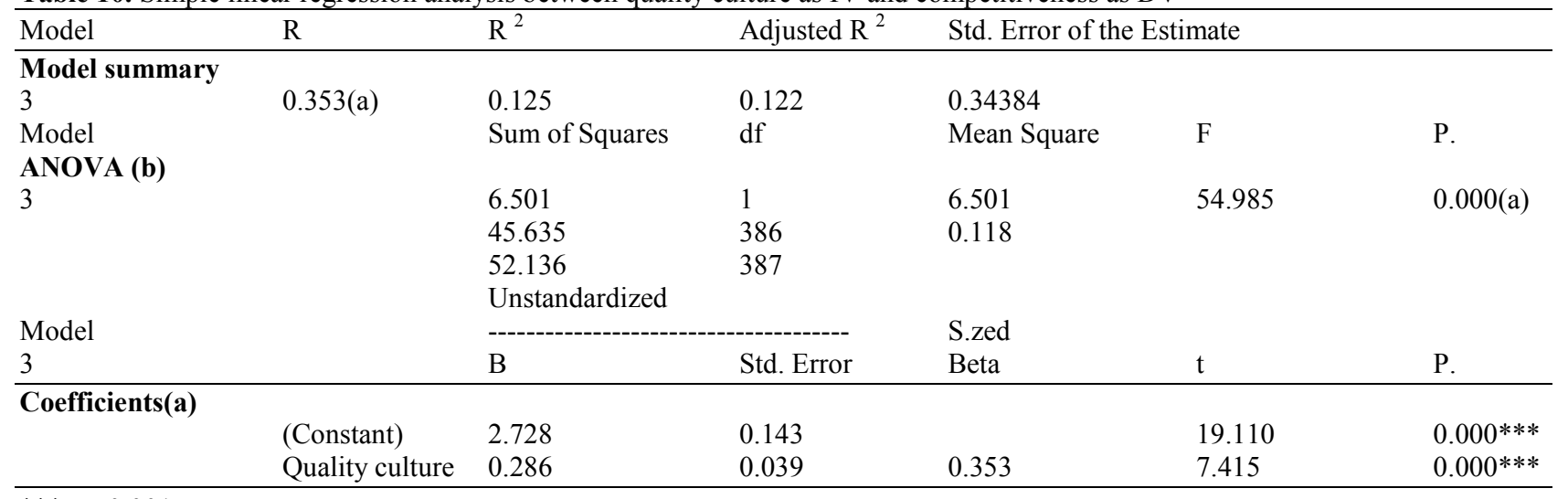

Table 11. Correlation coefficients of research factors $(\mathrm{N}=388)$

\begin{tabular}{lc}
\hline Factors & Competitivenes \\
\hline Competitiveness & $\mathrm{s}$ \\
Education and training & 1 \\
Customers focus & $0.129(*)$ \\
Information and analysis & $0.127(*)$ \\
Continuous improvement & $0.168(* *)$ \\
Process management & $0.154(* *)$ \\
mployee relations & $0.176(* *)$ \\
Top management & $0.567(* *)$ \\
Commitment & $0.133(* *)$ \\
Management of supplier & $0.168(* *)$ \\
\hline
\end{tabular}

$* * \mathrm{p}<0.01$

Table 12. Multiple linear regression analysis between Total quality management practices (TQMP) Factors as IVs and Competitiveness as DV

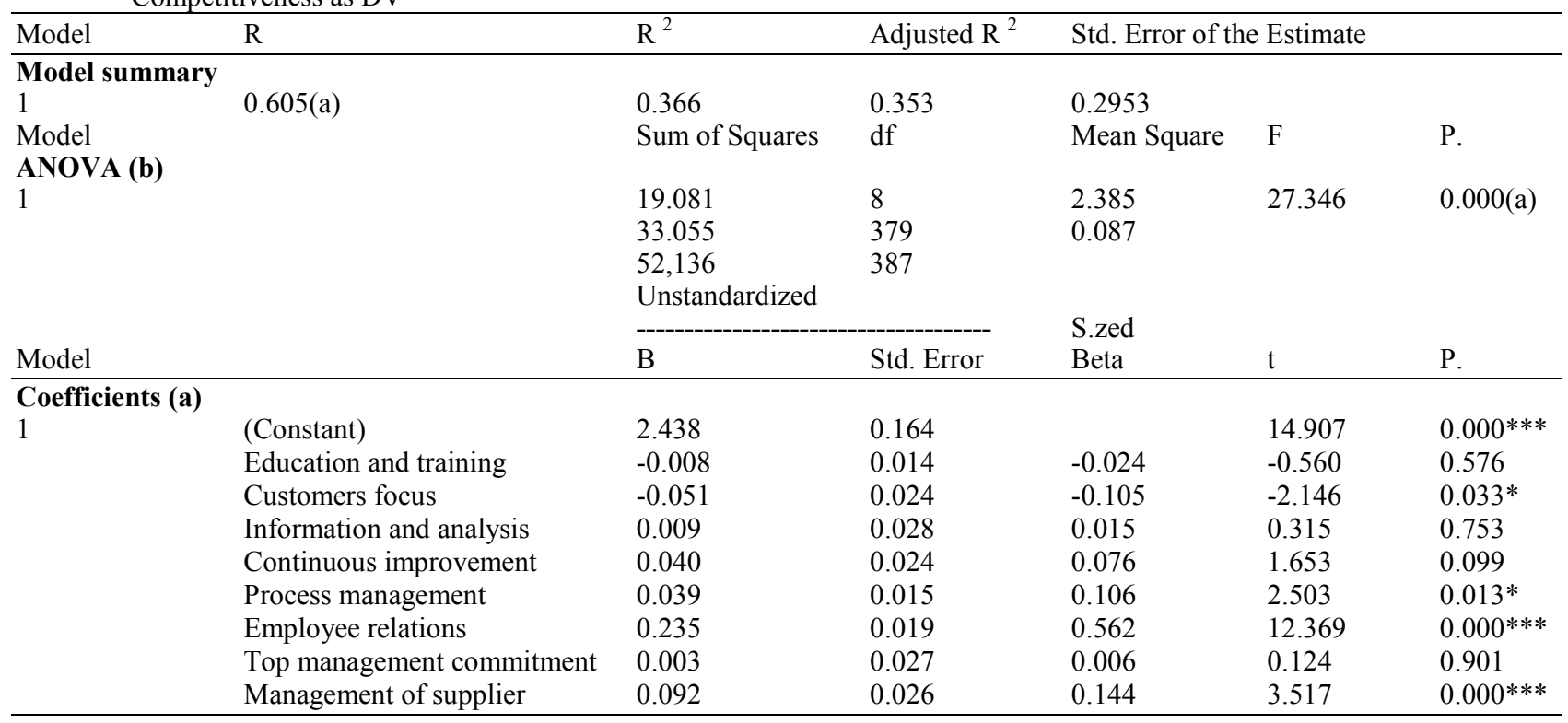

*; $<<0.05, * * * ; p<0.001$ 
As shown in Table 12, the results indicated that four TQMP (Customers Focus, Process management, Employee relations, Management of supplier) factors significantly affect contractors' competitiveness while four TQMP factors (Education and training, Information and Analysis, Continuous Improvement, Top Management Commitment) have no significant effect on contractors Competitiveness.

\section{CONCLUSION}

It discussed theories related to TQM, quality culture and competitiveness. Studies have revealed positive links between quality culture and competitiveness and between TQM and competitiveness. TQM is not a philosophy with flaws rather it's the TQM implementation that is carried out in manner full of flaws (Steele, 1993). This is the basis of the inability of the researchers and authors to reach a consensus of the critical elements of TQM success. Most authors advocate the top management involvement and consistent culture improvement while other authors differ on other elements related to TQM success in light of competitiveness. This study provided a description of the theoretical framework utilized and adopted in the present research. The framework is developed by adopting elements of prior researchers on the subject such as the analysis of the interrelationship between TQM practices, quality culture and firm's competitiveness. In view of the outcomes that emerged from the research, it can be said that the hypothesis was supported the mediating effect of quality culture on the relationship between total quality management practices and competitiveness. The independent variable also revealed a pattern whereby they sufficiently contributed to the competitiveness.

\section{REFERENCES}

Abdullah, M.M., J. Uli and J.J. Tari, 2009. The importance of soft factors for quality improvement and organisational performance. Int. J. Produc. Q. Manage., 4: 366-382. DOI: 10.1504/IJPQM.2009.023702

Ahmed, P.K., Y.E. Loh and M. Zairi, 1999. Cultures for continuous improvement and learning. Total Q. Manage., $\quad 10: \quad 426-434 . \quad$ DOI: 10.1080/0954412997361

Alotaibi, F., Yusoff, R.Z. and R. Islam, 2013. Relationship between total quality management practices and contractors competitiveness. Am. J. Applied Sci., 10: 247-252. DOI: 10.3844/ajassp.2013.247.252
Bagchi, T.P., 1997. Competitiveness and TQM: Is the synergy really a surprise. Proceedings of the International Conference on Portland Management and Technology Innovation in Technology Management-The Key to Global Leadership, Jul. 27-31, IEEE Xplore Press, Portland OR. DOI: 10.1109/PICMET.1997.653655

Coakes, S.J., 2003. SPSS Analysis Without Anguish: Version 11.0 for Windows. 1st Edn., John Wiley and Sons Australia Limited, Milton, ISBN-10: 0470802774, pp: 242.

Cohen, J., 1988. Statistical Power Analysis for the Behavioral Sciences. 2nd Edn., Lawrence Erlbaum Assoc Incorporated, Hillsdale, ISBN-10: 0805802835, pp: 567.

Douglas, T.J. and W.O. Judge, 2001. Total quality management implementation and competitive advantage: The role of structural control and exploration. Aca. Manage. J., 44: 158-158.

Fung, P. and A. Wong, 1995. TQM in Construction industry-hong kong context. Proceedings of the 1st International Conference on ISO 9000 and TQM, De Montfort University, Leicester, pp: 29-34.

Hair, J.F., R.L. Ta, R.L. Tataham and W.C. Black, 1998. 1st Edn., McGraw-Hill, Homewood, ISBN-10: 978025602848, pp: 244.

Hair, J.F., W.C. Black, B.J. Babin, R.E. Anderson and R.L. Tatham, 2006. Multivariate Data Analysis. 6th Edn., Prentice-Hall International, ISBN-10: 0130329290, pp: 899.

Holt, D.H., D.A. Ralston and R.H. Terpstra, 1994. Constraints on capitalism in Russia: The managerial psyche, social infrastructure and ideology $\mathrm{j}$. California Manage. Rev., 36: 124-41.

Jennings, M.B. and L. Loan, 2001. Misconceptions among nurses about evidence-based practice. J. Nurs. Scholarsh., 33: 121-127. PMID: 11419306

Kanji, G. and A. Wong, 1998. Business excellence model for supply chain management. Total Q. Manage., 10 : 1147-1168. DOI: 10.1080/0954412997127

Mahmood, W.Y., H.M. A. Abdul, M.S. Misnan, Z.M. Yusof and B. Bakri, 2006. Development of quality culture in the construction industry. Universiti Teknologi Malaysia.

Pallant, J., 2001. Spss Survival Manual: A Step-By-Step Guide to Data Analysis Using Spss for Windows. 1st Edn., Open University Press, ISBN-10: 0335208908, pp: 286. 
Porter, M.E., 2003. Building the microeconomic foundations of prosperity: Findings from the microeconomic competitiveness index. Institute for Strategy and Competitiveness, Harvard University.

Rad, A.M.M., 2006. The impact of organizational culture on the successful implementation of total quality management. TQM Mag., 18: 606-625. DOI: 10.1108/09544780610707101

Sekaran, U., 2003. Research Methods for Business: A Skill Building Approach. 4th Edn., Wiley, New York, ISBN-10: 0471384488, pp: 450.

Shi-Rong, L.I. and C. Guang-Kun, 2008. Evaluation on competitiveness of construction projects from the perspective of construction main bodies. Proceedings of the 4th International Conference on Wireless Communications, Networking and Mobile Computing, Oct. 12-14, IEEE Xplore Press, Dalian, pp: 1-4. DOI: 10.1109/WiCom.2008.1839
Steele, J., 1993. Implementing total quality management for long- and short-term bottom-line results. National Productivity Rev., 12: 425-441. DOI: 10.1002/npr.4040120313

Wong, A. and P. Fung, 1999. Total quality management in the construction industry in hong kong: A supply chain management perspective. Total Quality Manag., 10 : 199-208. DOI: $10.1080 / 0954412997956$ 